\title{
Estimating the Potential of Carbon Sequestration in Tree Species of Chintapalle Forest Range, Narsipatnam Division, Visakhapatnam, Andhra Pradesh, India
}

\author{
Korra Simhadri*, Syam Kumar Bariki**† and A.V.V.S. Swamy* \\ *Department of Environmental Sciences, Acharya Nagarjuna University, Guntur, A.P, India \\ $* * \dagger$ N S Raju Institute of Technology, Sontyam Visakhapatnam, A.P, India \\ $†$ Corresponding author: Syam Kumar Bariki; syamemmanuel@gmail.com
}

\section{Nat. Env. \& Poll. Tech.}

Website: www.neptjournal.com

Received: 29-05-2021

Revised: 28-06-2021

Accepted: 04-07-2021

\section{Key Words:}

Carbon sequestration

Tree species

Sequestration potential

Soil organic carbon

\begin{abstract}
The potential of carbon sequestration of tree species in the Chintapalle forest range, of Narsipatnam Division, was estimated by using a non-destructive method. The sequestration of 6033 trees belonging to 22 species was investigated; the approximate height of tree species and the diameter at breast height (DBH) were measured for the estimation of $\mathrm{CO}_{2}$ sequestration. The maximum weight of carbon was observed in Pongamia pinnata (L.) Pierre species i.e $(37987.06 \mathrm{~kg})$ and the minimum weight of carbon was noted in Phyllanthus emblica L. species i.e is $(61.8 \mathrm{~kg})$. The total carbon sequestrated by the entire tree species was $(2370614.0 \mathrm{~kg})$, The average carbon sequestered was $(39865.81 \mathrm{~kg})$. The highest sequestration was noted in the species P. pinnata (L.) Pierre i.e. $(139271.95 \mathrm{~kg}$ ) and the lowest $(226.79 \mathrm{~kg}$ ) was noted in the species $P$. emblica $\mathrm{L}$. The maximum average DBH with maximum carbon sequestration potential was observed in Ficus benghalensis L. species, with higher total green (AGW) observed in all sites, whereas minimum average DBH with minimum carbon sequestration potential was noted in Bambusa vulgaris species. The regression analysis tests the relationship between two variables. The height of trees has no significant impact on the amount of $\mathrm{CO}_{2}$ sequestered $\mathrm{F}$ $(32085087175.84,12946607900)=2.478262 ; \mathrm{P} \geq 0.05$, which indicates that the tree height plays an insignificant role in $\mathrm{CO}_{2}$ sequestration $(\beta=2713.28 \mathrm{P} \geq 0.05)$. The dependent variable $\mathrm{CO}_{2}$ sequestered was also regressed on the predictor variable soil organic carbon (SOC) to test the relationship. SOC insignificantly predicted $\mathrm{CO}_{2}$ sequestrated $\mathrm{F}(5.83,2.62)=0.2236 ; \mathrm{P} \geq 0.25$, indicating that the $\mathrm{SOC}$ has an insignificant role in $\mathrm{CO}_{2}$ sequestration $(\beta=102780.3 \mathrm{P} \geq 0.05)$. Insignificant relation was observed between the parameters SOC and height of tree species to the rate of carbon dioxide sequestered, and gave a regression equation of $y=10278 x+50863$ with $R^{2}=0.100 ; y=2713.285803 x-209800.8762$ with $R^{2}=0.553$ respectively.
\end{abstract}

\section{INTRODUCTION}

The forests absorb CO from the atmosphere and store it in the form of carbon, while green plants act as a sink for atmospheric $\mathrm{CO}$ by fixing carbon during the photosynthesis process, and excess carbon is stored as biomass. Terrestrial Carbon sequestration is one of the processes of (a) transforming atmospheric $\mathrm{CO}_{2}$ into components of biomass such as shrubs, trees, and Soil Organic Matter (SOM), through the process of photosynthesis and (b) assimilation of biomass into the soil as humus, which, involves the storing of atmospheric $\mathrm{CO}_{2}$ in these components of biomass successfully. According to IPCC (2003) and Gorte (2009), as photosynthesis occurs more, maximum $\mathrm{CO}_{2}$ is converted to biomass, lessening the carbon levels in the environment and sequestering it in plant tissues above and below ground, resulting in the growth of different parts (Chavan \& Rasal 2010). There is a great interest, in balancing the atmospheric $\mathrm{CO}_{2}$ concentration and decreasing $\mathrm{CO}_{2}$ emissions by using diverse types of land use patterns to increase the carbon sink of forestry. The role of forests (trees) in carbon cycles is quite predictable (Singh \& Lal 2000). Haripriya (2000, 2001, 2003), Manhas et al. (2006), Ravindranath et al. (1997), Chhabra and Dadhwal (2004), Gupta (2009), and Kaul et al. (2009) investigated changes in stratum and regional forest area as part of the study on the national forest carbon balance. According to the findings of Chhabra and Dadhwal (2004), forests are the largest suppliers of carbon, as well as a large sink for atmospheric carbon. Carbon dioxide emissions attributed to plants' vegetative mechanisms have increased significantly over the past decade. The use of existing $\mathrm{CO}_{2}$ from the atmosphere for photosynthetic processes provides a natural sink for excess carbon dioxide created by human activities. It is well known that global carbon dioxide emissions have increased to $18 \%$, reaching their first peak level after 1750 . In the past, there has been an annual increase of $1.5 \mathrm{ppb}$ in 
1990-2000, 2 ppb in 2001-2009, and 2.3 ppb in 2009-2010, which was the maximum (Chavan \& Rasal 2010).

According to the Food and Agricultural Organization (FAO), deforestation is responsible for $70 \%$ of all emissions in Africa (FAO 2005). Deforestation of tropical forests also destroys worldwide important carbon sinks that are presently sequestering $\mathrm{CO}_{2}$ from the atmosphere, and are crucial for climate stabilization (Stephens et al. 2007). The present models of global climate forecast a gradual rise in the atmospheric concentrations of greenhouse gases over the next century and associated increases in global temperature. Increased global temperatures have a number of negative consequences, including negative effects on human health, the spread of pathogenic illnesses, forest fires, heatstroke, salinity rises, glacier melting, and so on. It is therefore very important to stabilize the increase of temperature by regulating the carbon dioxide intensity in the atmosphere. Through the sequestration of carbon in producer communities, atmospheric carbon dioxide can be condensed by utilizing the carbon stored in all biomass in living vegetation, including woody and herbaceous plants above the soil as well as stems, branches, bark, seeds, and flora, as well as dead organic matter and Soil Organic Carbon (SOC). Some of the more stable compounds found in the humus may not turn over for hundreds to thousands of years. Scientists can enhance the sequestration process by applying agricultural methods that lessen the erosion of soil by wind, water, and oxidation of soil. The ecosystem in the terrestrial part is the main resource of carbon as well as a sink. The increase of carbon content in the US is due to erosion by water and wind, and uncultivated land contains an average of 1329 MMTC of carbon while poor agricultural practices contribute five percent of the global greenhouse gas emissions. The 90-230 MMTC emitted annually from arable land and pastures in the tropics accounts for the largest portion of that global amount (Crookshank 1999). Trees in urban and rural settings provide a two-fold advantage: direct carbon storage and natural ecosystem stability with increased nutrient recycling, as well as the maintenance of climatic conditions by biogeochemical processes in the carbon reduction process of the atmosphere.

Estimations of biomass and stored carbon for the main tree species in the forest areas of the Eastern Ghats of Visakhapatnam, located in the state of Andhra Pradesh, India, were carried out in this study (taken during 2019-20) using three vital parameters namely Diameter at Breast Height (DBH), the height of the tree (h), and form factor (ratio of the square of radius at breast height to the radius of the tree at base). To combat global warming, the Kyoto Protocol proposed that carbon emissions be minimized by reducing fossil fuel emissions or by accumulating carbon in terrestrial ecosystem foliage and soil. For estimating the tree biomass, a non-destructive technique i.e., regression or allometric equations were used. Carbon sequestration can be achieved by accumulating all components of the ecosystem's carbon pool, such as SOC (soil organic carbon) content at 0 to $15 \mathrm{~cm}$ depth, as well as carbon can be stored in aboveground biomass (AGB), and belowground biomass (BGB). In the process, tree biomass is directly estimated by using the Diameter at Breast Height (DBH) values (Brown 1997). Throughout the world, allometric equations have been used for the determination of AGB and BGB and the carbon stored within the ecosystem components. Carbon sequestration through planted forests serves as a sizeable sink for atmospheric $\mathrm{CO}_{2}$ both in temperate and tropical regions (Houghton et al. 2000, Houghton 1985, 1990, Fang et al. 2001). As a result of its total commoditization, $\mathrm{CO}_{2}$ sequestration has garnered a significant amount of attention in the present and past. The accurate measurement of forest carbon sink is complex without the precise assessment of biomass. Therefore, the objective of this study is to calculate, approximately, the $\mathrm{CO}_{2}$ sequestration potential of different types of tree species of the reserve forest blocks of Chintapalle, forest range of Narsipatnam Division, Visakhapatnam, Andhra Pradesh, India.

\section{MATERIALS AND METHODS}

\section{Study Area}

The Chinthapalli forest range, of Narsipatnam, is located on the northeast of Visakhapatnam district, Andhra Pradesh. It lies between $17^{0} 44^{\prime} 22^{\prime \prime}$ North latitude to $18^{\circ} 04^{\prime} 29^{\prime \prime}$ North and $82^{\circ} 16^{\prime} 00^{\prime \prime}$ East to $82^{0} 38^{\prime} 04^{\prime \prime}$ East. Temperatures in hill track villages range from $2^{\circ}$ to $30^{\circ} \mathrm{C}$, as measured at the local agriculture research station in Chintapalle, Lambasingi area, and travelers refer to this place as Andhra Kashmir as temperatures are as low as $0^{\circ} \mathrm{C}$ in December and January. Depending on topographical conditions, the block and its surroundings can be divided into four categories viz. mountainous region, highlands tracks, rising and falling plains, and plains. The main hill ranges of the study area are Chintooru forest, Lothugedda and Chintapalli town, and Thanjangi.

\section{Sampling}

For this investigation, sampling locations were identified in the Chintaaplle block of the Narsipatnam forest division region, namely: Chinrooru (Lothu Gedda Junction), Tajangi, Chinnagedda, and St. Ann's School colony. These sites were selected as the sampling area due to their wide green forest with low rural anthropogenic emission of carbon components. A total of six thousand and thirty-three (6033) trees belonging to twenty-two (22) different tree species were selected for the study. They are: Ficus hispida L.f, 
Trichilia connaroides (Wight \& Arn.) Bentv, Bombax ceiba L., Artocarpus heterophyllus Lam., Tamarindus indica L., Mangifera indica L., Eucalyptus globules, Grevillea robusta, Ficus religosa, Semecarpus anacardium L.f., Bambusa vulgaris, Caryota urens L., Pongamia pinnata (L.) Pierre, Tectona grandis L.f, Delonix regia, Ficus benghalensis L., and Syzygium cumini (L.) Skeels.

\section{Analytical Methods}

The non-destructive method was used for the determination of the above-ground weight (total green) dry weight, and $\mathrm{CO}_{2}$ Sequestration $(\mathrm{kg})$, and the total organic carbon of each tree species was evaluated. SOC was determined in the forest sites by the IS2720 \& ASTM methods (Table 5). There are two approaches for evaluating the biomass concentration of tree species. (a) The biomass density was directly estimated through biomass regression or allometric equations. (b) By converting wood volume estimations to biomass density using biomass factors (Brown 1997). The use of allometric equations is a central step in evaluating above and below-ground biomass (Brown et al. 1989, 1991). In India, several authors had published biomass estimations using allometric equations for a few tree species and the diameter above $10 \mathrm{~cm}$ at breast height (Lodhiyal et al. 2002, Lodhiyal \& Lodhiyal 2003). The methodology used included statistics and linear regression models and figures.

\section{Tree Height (TH) and Diameter at Breast Height (DBH)}

For measuring the circumference of a tree to determine the (DBH) Diameter at Breast Height of the tree species, the circumference of the tree trunk at $1.3 \mathrm{~m}$ from the ground level was considered, while for trees with a circumference less than or equal to $10 \mathrm{~cm}$, direct measurement leaving the height from the ground level was performed (Fig. 1). The total height of the tree species was estimated by measuring with a tape by climbing, and by straight measurement aided by a pole and the affirmation by calculating the Thiodolite angle and sides.

The angle between the top of the tree and the view of the eye at breast height () angle was used to determine the tree height of the species. The angle ACB between the top of a tree and the distance (b) at the observer point at DBH is considered. Hence the height of the tree species was calculated if $(\alpha)$ is the angle between the top of the tree and the eye view, $(\mathrm{H})$ is the tree height in meters/inches, $(\mathrm{c})$ is the slope between eye view and the treetop, (b) is the distance between observer and tree and $(\mathrm{h})$ is the height of horizontal plane of Thiodolite instrument. Therefore, tree species height was calculated by the below formula:

$$
\mathrm{H}=\mathrm{h}+\mathrm{b} \tan \alpha
$$

\section{Determination of Carbon Sequestration Potential and Biomass of Tree Species}

The method suggested by Chavan and Rasal (2010) was directly applied, five stages as follows:

- The total (green) weight of a tree is calculated as follows: $\mathrm{W}=$ Above-ground weight of the tree in kilogram $(\mathrm{kg})$; $\mathrm{D}=$ Diameter of the trunk in inches; $\mathrm{H}=$ Height of tree in meters. $\mathrm{W}=0.25 \times \mathrm{D}^{2} \times \mathrm{H}$ for trees with $\mathrm{D} 10$ and $\mathrm{W}$ $=0.15 \times \mathrm{D}^{2} \times \mathrm{H}$ for trees with $\mathrm{D} 11$. The root system of a tree weighs about $120 \%$ of the tree's above-ground weight. Therefore, for determining the total green weight of the tree, multiply the above-ground weight of the tree by $120 \%$.

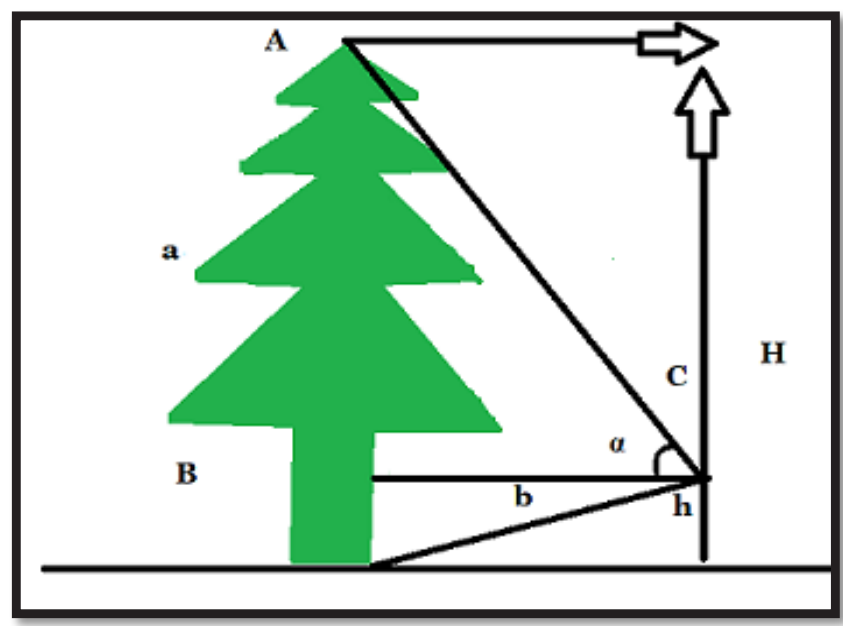

Fig. 1: Determination of tree height by thiodolite at $\mathrm{DBH}$. 
- The dry weight of a tree is based on a University of Nebraska publication (Chavan \& Rasal 2010). The tree's dry weight was determined by multiplying the tree's weight by 72.5 percent.

- The average carbon content of a tree is 50 percent of its total volume (weight of carbon). As a result, the dry weight of carbon in the tree was determined by multiplying the dry weight of carbon in the tree.

- Carbon dioxide sequestration weight $\left(\mathrm{CO}_{2}\right)$ is composed of one molecule of carbon and 2 molecules of oxygen and the atomic weight of Carbon is 12.001115; the atom- ic weight of Oxygen is 15.9994 As a result, the weight of $\mathrm{CO}_{2}$ is $\mathrm{C}+(2 \mathrm{X} \mathrm{O})=43.999915$, and the $\mathrm{CO}_{2}$ to $\mathrm{C}$ ratio is $43.999915 / 12.001115=3.6663$. To calculate the weight of carbon dioxide sequestered in the tree, multiply the weight of carbon in the tree by 3.6663 .

- The weight of $\mathrm{CO}_{2}$ sequestered in the tree per year was calculated by dividing the weight of carbon dioxide sequestered in the tree by the age of the tree. Hence, in the present study, we used the allometric equation using tree diameter to estimate above-ground biomass following Brown et al. (1989).

Table 1: $\mathrm{CO}_{2}$ Sequestration of tree species at Chintooru, Lothugedda Junction in (Block-6).

\begin{tabular}{|c|c|c|c|c|c|c|c|c|c|c|}
\hline \multirow{2}{*}{ 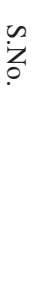 } & \multirow[b]{2}{*}{ 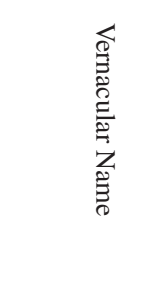 } & \multirow[b]{2}{*}{ 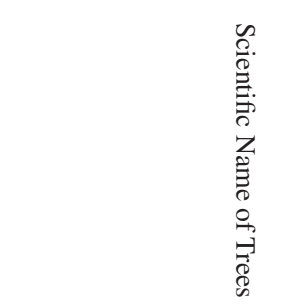 } & \multirow[b]{2}{*}{$\begin{array}{l}Z \\
\Xi \\
\Xi \\
\Xi \\
\Phi \\
0 \\
\stackrel{9}{G} \\
\exists \\
\mathbb{8} \\
\Phi\end{array}$} & \multirow[b]{2}{*}{ 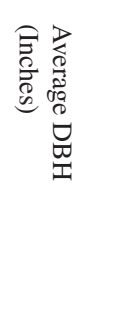 } & \multirow[b]{2}{*}{ 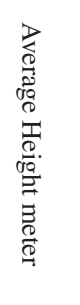 } & \multicolumn{5}{|c|}{ Weight from tree species $(\mathrm{kg})$} \\
\hline & & & & & & 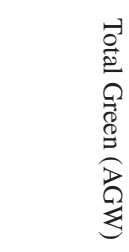 & 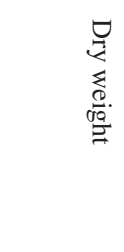 & 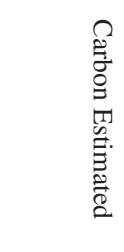 & 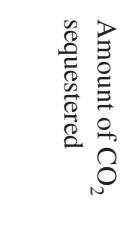 & 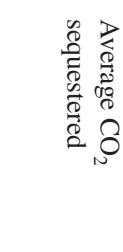 \\
\hline 1 & Boddechettu & Ficus hispida L.f & 42 & 15.74 & 7.5 & 334.45 & 242.47 & 121.23 & 444.46 & 10.58 \\
\hline 2 & Usiri & Phyllanthus emblica $\mathrm{L}$. & 25 & 13.77 & 5 & 170.65 & 123.72 & 61.86 & 226.79 & 9.07 \\
\hline 3 & Peddaturayi & Delonix regia & 17 & 106.30 & 12 & 24407.33 & 17695.31 & 8847.65 & 32438.13 & 1908.12 \\
\hline 4 & Neredu & $\begin{array}{l}\text { Syzygium cumini (L.) } \\
\text { Skeels }\end{array}$ & 46 & 104.33 & 16 & 31348.07 & 22727.35 & 11363.67 & 41662.62 & 905.70 \\
\hline 5 & Teku & Tectona grandis L.f & 450 & 82.67 & 18 & 22143.22 & 16053.83 & 8026.91 & 29429.06 & 65.39 \\
\hline 6 & Panasa & $\begin{array}{l}\text { Artocarpus heterophyl- } \\
\text { lus Lam. }\end{array}$ & 73 & 133.85 & 17 & 54822.41 & 39746.24 & 19873.12 & 72860.81 & 998.10 \\
\hline 7 & Chinta & Tamarindus indica L. & 67 & 92.51 & 16.5 & 25417.55 & 18427.72 & 9213.63 & 22779.93 & 339.99 \\
\hline 8 & Mamidi & Mangifera indica $\mathrm{L}$. & 98 & 122.04 & 21 & 56298.41 & 41273.09 & 20636.54 & 75659.74 & 772.03 \\
\hline 9 & Neelagiri & Eucalyptus globulus & 41 & 66.92 & 28 & 22570.56 & 16363.65 & 8181.82 & 29997.0 & 731.63 \\
\hline 10 & Silver Oak & Grevillea robusta & 200 & 47.24 & 23 & 9238.89 & 6698.19 & 3349.09 & 12278.76 & 61.39 \\
\hline 11 & Nallajeedi & $\begin{array}{l}\text { Semecarpus anacardium } \\
\text { L.f. }\end{array}$ & 32 & 17.71 & 8 & 451.64 & 327.43 & 163.71 & 600.20 & 18.20 \\
\hline 12 & Veduru & Bambusa vulgaris & 27 & 7.87 & 11 & 204.39 & 148.18 & 74.09 & 271.63 & 10.06 \\
\hline 13 & Jeelugu & Caryotaurens L. & 35 & 90.55 & 17.5 & 25827.80 & 18725.15 & 9362.57 & 34325.99 & 980.74 \\
\hline 14 & Nalla Maddi & Terminalia alata Roth. & 43 & 59.05 & 19.5 & 12239.02 & 8873.28 & 4436.91 & 16267.04 & 378.30 \\
\hline 15 & Tella Maddi & $\begin{array}{l}\text { Terminalia arjuna (Roxb. } \\
\text { ex DC.) Wight \&Arn. }\end{array}$ & 38 & 47.24 & 18 & 7230.44 & 5242.1 & 2621.09 & 9609.70 & 252.88 \\
\hline 16 & Kanugu & $\begin{array}{l}\text { Pongamia pinnata }(\mathrm{L} .) \\
\text { Pierre }\end{array}$ & 7 & 62.99 & 12 & 8570.31 & 6213.47 & 3106.47 & 11389.25 & 1627.03 \\
\hline 17 & Sampangi & $\begin{array}{l}\text { Micheliachampaca (L.) } \\
\text { Baill. ex Pierre }\end{array}$ & 5 & 66.92 & 17.5 & 14106.60 & 10227.28 & 5113.64 & 18748.13 & 3749.62 \\
\hline 18 & Gumpena & $\begin{array}{l}\text { Lanneacoro mandelica } \\
\text { (Houtt.) Merr. }\end{array}$ & 23 & 20.07 & 8 & 580.03 & 420.52 & 210.26 & 770.87 & 33.51 \\
\hline \multicolumn{2}{|c|}{ TOTAL } & & 1269 & 1157.77 & 275.5 & 315961.8 & 229529 & 114764.3 & 409760.1 & 12852.34 \\
\hline
\end{tabular}




\section{Soil Sampling}

To determine the SOC (Soil organic Carbon) from the study sites, the soil samples were collected from the sites by using standard sampling procedures, given for soil sampling. All the soil samples were collected from the depth of $0-15 \mathrm{~cm}$ with two replicates. The physicochemical parameters such as - soil texture, $\mathrm{pH}$, and soil organic carbon, were analyzed by standard methods, as per IS2720 \& ASTM methods.

\section{RESULTS AND DISCUSSION}

The carbon dioxide sequestration and carbon storage capability of (6033) tree species belonging to (22) tree species were assessed. The evaluation was divided into four sections, as shown in Tables 1-4. Fig. 2. shows the relationship between above-ground weight and below-ground weight (AGW). Fig. 2 also shows the relationship between the total carbon dioxide sequestered and the above-ground weight (AGW) and dry weight of the studied trees in the sites.

The total carbon dioxide sequestered and calculations of carbon dioxide sequestered at the study locations are shown in Tables 1 to 4 . The amount of $\mathrm{CO}_{2}$ sequestered in block-1, Chintooru is $(409,760.1 \mathrm{~kg})$; block-2 Chinnagedda is $(568,891.3 \mathrm{~kg})$; St.Anns School Colony Chintapalli, Block-3 is $(659,853 \mathrm{~kg})$ and block-4 Tajangi is $(732,109.2 \mathrm{~kg})$. A large amount of $\mathrm{CO}_{2}$ sequestration was recorded at block-4 Tajangi site, which may be due to the presence of more tree species, and the long age of species. A large amount of $\mathrm{CO}_{2}$ sequestered was found in the species $P$. pinnata (L.) Pierre, and $F$. benghalensis $\mathrm{L}$, and a low amount of carbon dioxide sequestrated was observed in block-1 Chinnagedda in $P$. emblica L. species. The maximum weight of carbon was observed in P. pinnata (L.) Pierre) species, i.e. (37987.06 $\mathrm{kg}$ ) and minimum weight of carbon was noted in the species P. emblica L. species i.e is $(61.8 \mathrm{~kg})$. The maximum assessment of carbon dioxide sequestration is especially noted in $F$. benghalensis species, because of its higher (AGW) compared to other species. In an earlier study by Chavan and Rasal (2010), similar findings were recorded. The estimated average $\mathrm{C}$-stock of $P$. pinnata was $23.52 \mathrm{tC}$ ha- 1 in Site- 1 and 72.70 tC ha- 1 in Site- 2 and an average equivalent of 86.34 $\mathrm{tCO}_{2}$ ha- 1 and $266.84 \mathrm{tCO}_{2}$ ha-1 has been stored (Annissa Muhammed et al. 2013). A similar study performed by Cox (2012), in California State University, Northridge (CSUN), showed that the total carbon dioxide sequestered by the trees in the campus was 154 tons per year. Haghparast (2013) also recorded a whole of 1694.5 tons of carbon sequestered in seventy-six plots of Pune University. De Villiers et al. (2014) reported the sequestration potential of 4139 trees to be 5809 tons in New Zealand University. Vucetich et al. (2000) and Pussinen et al. (2002) reported that the carbon stock depends upon the type of tree species, location properties, spacing, environment conditions, age class distribution, etc. The three dominant species of the entire site are $T$. grandis L.f, $M$. indica and T. indica $\mathrm{L}$. In contrast to it, a study conducted by Kaur and Sharma (2014) in the agricultural fields of block Ramgarh revealed $M$. indica as the densest tree species with a density value of 1.9 trees per hectare. Rowntree and Nowak, (1991) stated that the broader the leaves, the thicker the crown cover, and consequently the denser the cluster, the more $\mathrm{CO}_{2}$ sequestered by trees.

From the results obtained, it clearly indicates that the native species like P. pinnata (L.) Pierre, F. benghalensis, L., T. grandis L.f, $M$. indica, and T. indica L. have a maximum

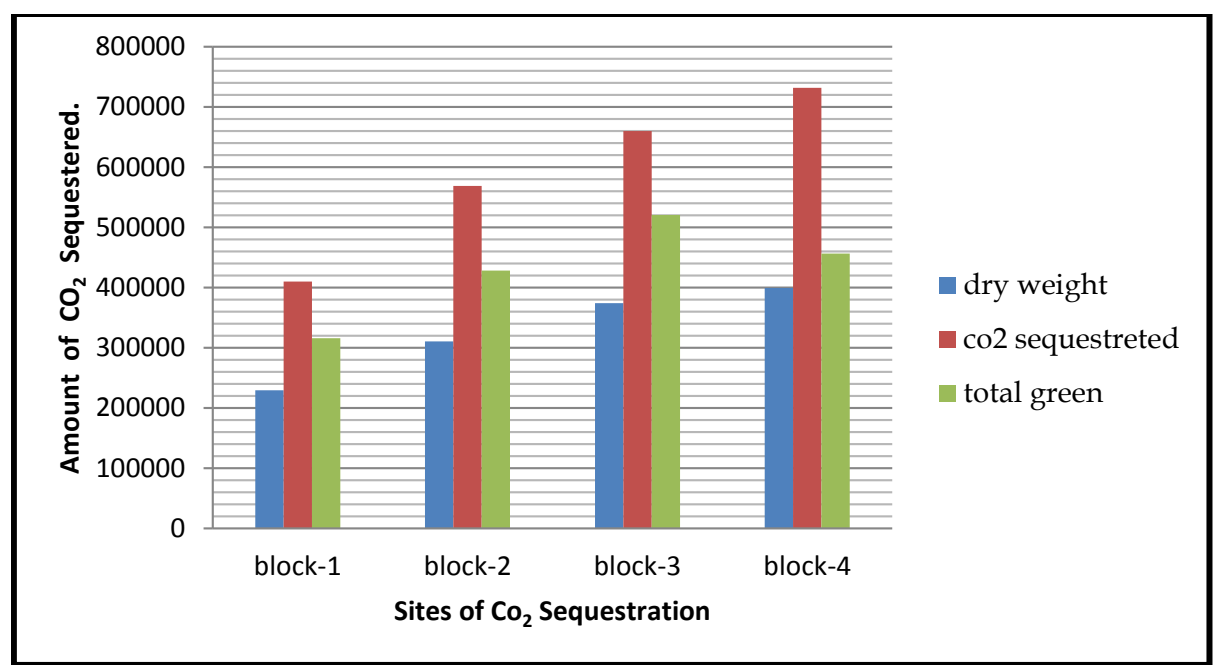

Fig. 2: Relationship between dry weight and the total amount of sequestered $\mathrm{CO}_{2}$. 
Table 2: $\mathrm{CO}_{2}$ Sequestration of tree species at Chinnagedda, (Block-7).

\begin{tabular}{|c|c|c|c|c|c|c|c|c|c|c|}
\hline \multirow[b]{2}{*}{ ¿n } & \multirow[b]{2}{*}{ 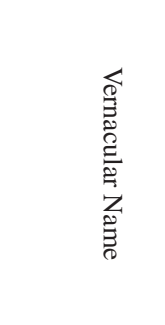 } & \multirow{2}{*}{ 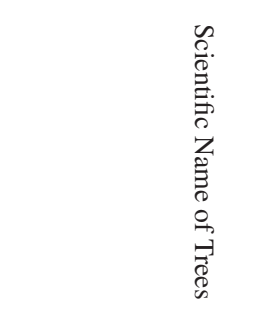 } & \multirow[b]{2}{*}{ 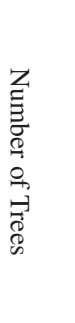 } & & \multirow{2}{*}{ 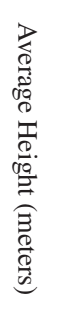 } & \multicolumn{5}{|c|}{ Weight from tree species $(\mathrm{kg})$} \\
\hline & & & & 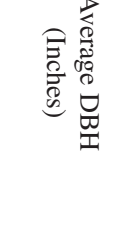 & & 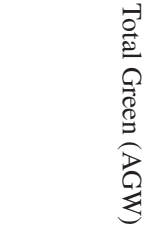 & 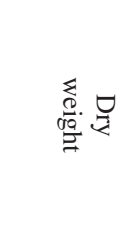 & 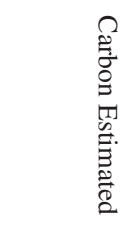 & 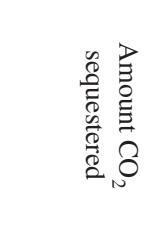 & $\begin{array}{ll}0 & 8 \\
0 & 2 \\
0 & 9 \\
0 & 0 \\
0 & 0 \\
0 & 0 \\
0 & 0 \\
0 & 0 \\
0 & 0\end{array}$ \\
\hline 1 & Garugu & $\begin{array}{l}\text { Trichilia connaroides } \\
\text { (Wight \& Arn.) Bentv }\end{array}$ & 78 & 14.96 & 5 & 201.42 & 146.42 & 73.01 & 267.69 & 3.43 \\
\hline 2 & Bodda chettu & Ficus hispida L.f. & 56 & 21.65 & 8 & 674.96 & 489.34 & 244.67 & 897.04 & 16.01 \\
\hline 3 & Peddaturayi & Delonix regia & 47 & 90.55 & 12 & 17710.49 & 12840.10 & 6420.05 & 23537.84 & 500.80 \\
\hline 4 & Teku & Tectona grandis L.f & 850 & 98.42 & 17.5 & 30512.46 & 22121.53 & 11060.76 & 40552.09 & 47.70 \\
\hline 5 & Panasa & $\begin{array}{l}\text { Artocarpus hetero- } \\
\text { phyllus Lam. }\end{array}$ & 284 & 102.36 & 16 & 30175.40 & 21877.16 & 10938.58 & 40104.12 & 141.211 \\
\hline 6 & Chinta & Tamarindus indica $\mathrm{L}$. & 105 & 96.45 & 15.5 & 25954.26 & 18816.83 & 9408.41 & 34494.88 & 328.51 \\
\hline 7 & Mamidi & Mangifera indica $\mathrm{L}$. & 368 & 151.57 & 21 & 86839.69 & 62958.78 & 31479.39 & 115412.88 & 313.62 \\
\hline 8 & Neelagiri & Eucalyptus globulus & 250 & 62.99 & 32 & 22854.18 & 16569.28 & 8284.64 & 30373.98 & 121.49 \\
\hline 9 & Silver Oak & Grevillea robusta & 325 & 49.21 & 24 & 10461.41 & 7584.52 & 3792.26 & 13903.57 & 42.78 \\
\hline 10 & Ravi & Ficus religiosa $\mathrm{L}$. & 24 & 108.26 & 20 & 42192.81 & 30589.79 & 15294.89 & 56075.68 & 2336.48 \\
\hline 11 & Nallajeedi & $\begin{array}{l}\text { Semecarpus anacar- } \\
\text { dium L.f. }\end{array}$ & 30 & 26.77 & 7.50 & 967.45 & 701.40 & 350.70 & 1285.77 & 42.859 \\
\hline 12 & Veduru & Bambusa vulgaris & 102 & 7.87 & 11 & 204.39 & 148.18 & 74.09 & 271.63 & 2.66 \\
\hline 13 & Jeelugu & Caryota urens $L$. & 50 & 72.51 & 14.5 & 13722.59 & 9948.88 & 4974.44 & 18237.79 & 364.75 \\
\hline 14 & Sampangi & $\begin{array}{l}\text { Michelia champaca } \\
\text { (L.) Baill.ex Pierre }\end{array}$ & 18 & 88.20 & 16 & 22404.21 & 16243.05 & 8121.52 & 29775.95 & 1654.21 \\
\hline 15 & Marri Chettu & Ficus benghalensis L. & 6 & 177.16 & 18 & 101689.55 & 73724.92 & 36862.46 & 135148.85 & 22524.80 \\
\hline \multirow[t]{2}{*}{16} & Neredu & $\begin{array}{l}\text { Syzygiumcumini (L.) } \\
\text { Skeels }\end{array}$ & 87 & 89.2 & 15 & 21482.92 & 15575.12 & 7787.56 & 28551.53 & 328.17 \\
\hline & \multicolumn{2}{|c|}{ TOTAL } & 2680 & 1258.13 & 253 & 428048.2 & 310335.3 & 155167.4 & 568891.3 & 28769.48 \\
\hline
\end{tabular}

amount of carbon dioxide sequestration potential than all the other tree species. Fig. 2, shows the relationship between the dry weights of tree species of diverse sampling sites with the amount of carbon dioxide sequestered. From this figure, it was observed that the total green obtained is the AGW (Above ground weight) $(\mathrm{kg})$ is directly proportional to the amount of $\mathrm{CO}_{2}$ sequestered, and dry weight obtained $(\mathrm{kg})$ is also directly proportional to the amount of carbon dioxide sequestered. This phenomenon was mostly observed in block-4 Thajangi, where the number of tree species is more compared to all the other blocks is $(732,109.2 \mathrm{~kg})$. In block-01, the numbers of trees are scanty which declines the total green (AGW) and dry weight of the tree and shows a deviation in the quantity of $\mathrm{CO}_{2}$ sequestrated i.e. $(409,760.1 \mathrm{~kg}$.). Gibbs et al. (2007) provided similar findings, finding a progressive direct link between total green (AGW), the dry weight of the tree, and the amount of carbon dioxide sequestered by trees. In the four sampling sites, it was observed from Tables 1-4, that the species like P. pinnata (L.), A. heterophyllus Lam, T. indica L. M. indica L. F. religiosa L., F. benghalensis L. Pierre, and T. grandis are with maximum $\mathrm{CO}_{2}$ sequestration. Similarly, the lowest $\mathrm{CO}_{2}$ sequestration was recorded in B. vulgaris and P. emblica L., species. $(70.72 ; 226.79 \mathrm{~kg})$ respectively.

Fig. 3 and Table 6 interpret the relationship between the heights of the tree to the amount of $\mathrm{CO}_{2}$ sequestrated. Fig. 3 shows the tree height carries an insignificant impact on $\mathrm{CO}_{2}$ sequestered. The dependent variable $\mathrm{CO}_{2}$ sequestered was regressed on the predicting variable tree height to test the relationship. The height of tree species insignificantly pre- 
Table 3: $\mathrm{CO}_{2}$ Sequestration of tree species from Chintapalli, St. Ann's School, (Block-8).

\begin{tabular}{|c|c|c|c|c|c|c|c|c|c|c|}
\hline \multirow[t]{2}{*}{ U } & \multirow{2}{*}{ 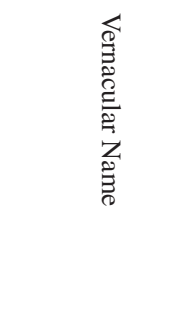 } & \multirow{2}{*}{ 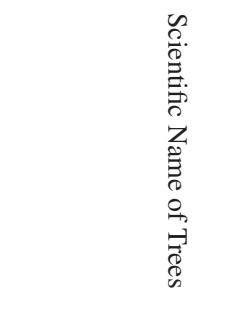 } & \multirow{2}{*}{ 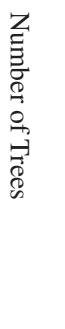 } & \multirow{2}{*}{ 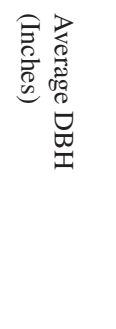 } & \multirow{2}{*}{ 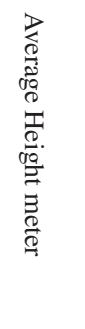 } & \multicolumn{5}{|c|}{ Weight from tree species $(\mathrm{kg})$} \\
\hline & & & & & & \multicolumn{2}{|c|}{ 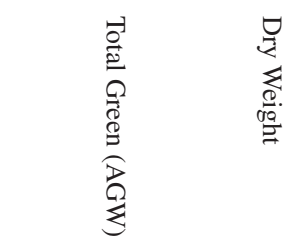 } & 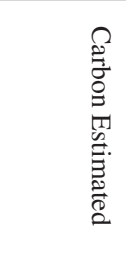 & 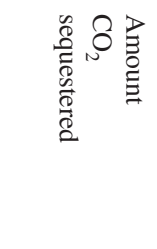 & 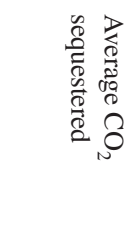 \\
\hline 1 & BoddaChettu & Ficus hispida L.f & 20 & 30.70 & 9.5 & 1611.65 & 1168.45 & 584.22 & 2141.94 & 107.09 \\
\hline 2 & Burugu & Bombax Ceiba L. & 15 & 84.64 & 14 & 18053.10 & 13088.59 & 6544.24 & 23993.18 & 1599.54 \\
\hline 3 & Chinta & $\begin{array}{l}\text { Tamarindus indica } \\
\text { L. }\end{array}$ & 78 & 114.17 & 17 & 39886.45 & 28917.67 & 14458.83 & 53010.43 & 679.62 \\
\hline 4 & Mamidi & $\begin{array}{l}\text { Mangifera indica } \\
\text { L. }\end{array}$ & 86 & 127.95 & 22.5 & 66303.37 & 48069.94 & 24034.97 & 88119.41 & 1024.64 \\
\hline 5 & Neelagiri & $\begin{array}{l}\text { Eucalyptus glob- } \\
\text { ulus }\end{array}$ & 52 & 64.96 & 31 & 23546.59 & 17071.20 & 8535.60 & 31294.08 & 601.80 \\
\hline 6 & Silver Oak & Grevillea robusta & 180 & 59.05 & 26.5 & 16632.52 & 12058.58 & 6029.29 & 22105.18 & 122.80 \\
\hline 7 & Ravi & Ficus religiosa $\mathrm{L}$. & 21 & 106.29 & 22 & 44738.35 & 32435.30 & 16217.65 & 59458.77 & 2831.37 \\
\hline 8 & Jeelugu & Caryotaurens L. & 15 & 98.42 & 16 & 27897.10 & 20225.40 & 10112.70 & 37076.20 & 2471.74 \\
\hline 9 & Kanugu & $\begin{array}{l}\text { Pongamia pinnata } \\
\text { (L.) Pierre }\end{array}$ & 10 & 84.64 & 11.5 & 14829.33 & 7414.66 & 10751.26 & 39417.37 & 3941.73 \\
\hline 10 & Panasa & $\begin{array}{l}\text { Artocarpus hetero- } \\
\text { phyllus Lam. }\end{array}$ & 52 & 127.95 & 18 & 53042.69 & 38455.95 & 19227.97 & 70495.53 & 1355.68 \\
\hline 11 & Marri Chettu & $\begin{array}{l}\text { Ficus benghalen- } \\
\text { sis L. }\end{array}$ & 9 & 167.32 & 19 & 95746.25 & 69416.03 & 34708.01 & 127250.01 & 14138.89 \\
\hline 12 & Teku & Tectona grandis L.f & 55 & 74.80 & 19.5 & 12549.79 & 9098.60 & 4549.30 & 16679.10 & 303.25 \\
\hline 13 & Medi & Ficus racemosa $\mathrm{L}$. & 18 & 25.59 & 8 & 942.98 & 683.66 & 431.83 & 1253.25 & 69.62 \\
\hline 14 & Neredu & $\begin{array}{l}\text { Syzygium cumini } \\
\text { (L.) Skeels }\end{array}$ & 15 & 85.82 & 17 & 22537.12 & 16339.41 & 8169.70 & 29952.59 & 1996.83 \\
\hline 15 & Gumpena & $\begin{array}{l}\text { Lannea coroman- } \\
\text { delica (Houtt.) } \\
\text { Merr. }\end{array}$ & 25 & 19.68 & 8.5 & 592.57 & 429.61 & 214.80 & 787.54 & 31.50 \\
\hline 16 & Nalla Maddi & $\begin{array}{l}\text { Terminalia alata } \\
\text { Roth. }\end{array}$ & 18 & 102.36 & 18 & 33947.32 & 24611.81 & 12305.90 & 45117.14 & 2506.50 \\
\hline 17 & Tella Maddi & $\begin{array}{l}\text { Terminalia arjuna } \\
\text { (Roxb. ex DC.) }\end{array}$ & 23 & 109.44 & 21 & 45273.48 & 32823.27 & 16411.63 & 8205.81 & 30084.99 \\
\hline 18 & Mulu maddi & $\begin{array}{l}\text { Bridelia retusa (L.) } \\
\text { A. Juss. }\end{array}$ & 15 & $11 . \mathrm{O} 2$ & 8 & 174.87 & 126.78 & 63.39 & 232.41 & 15.49 \\
\hline 19 & Karaka & $\begin{array}{l}\text { Terminalia chebu- } \\
\text { la Retz }\end{array}$ & 27 & 33.85 & 12 & 2455.23 & 1780.04 & 890.02 & 3263.09 & 120.85 \\
\hline TO & & & 734 & 1517.63 & 319 & 520760.8 & 374215 & 194241.3 & 659853 & 64003.93 \\
\hline
\end{tabular}

dicted $\mathrm{CO}_{2}$ sequestrated $\mathrm{F}$ (32085087175.84, 12946607900) $=2.478262 ; \mathrm{P} \geq 0.05$, which indicates that the tree height has an insignificant role in $\mathrm{CO}_{2}$ sequestration $(\beta=2713.28 \mathrm{P} \geq$ $0.05)$. The regression analysis indicates clearly that there is no direct relationship of the tree height, moreover, $\mathrm{R}^{2}=0.553$, which indicates the regression model explains $55.3 \%$ of the variance. Most of the research works revealed that AGB is strongly correlated with tree diameter (Brown 1997, Brown \& Lugo 1984, Clark et al. 2001). Also, it is accepted that a simple model with the only diameter as the input is a good estimator of above-ground biomass (Brown 1997, Nelson et al. 1999, Clark et al. 2001, Djomoa et al. 2010). There 
Table 4: $\mathrm{CO}_{2}$ Sequestration Assessment of tree species at Thajangi, (Block-9).

\begin{tabular}{|c|c|c|c|c|c|c|c|c|c|c|}
\hline \multirow[b]{2}{*}{$\stackrel{n}{Z}$} & \multirow{2}{*}{ 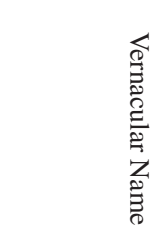 } & \multirow{2}{*}{ 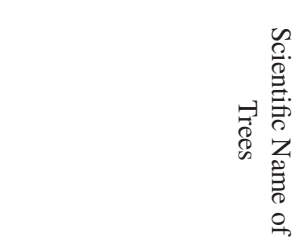 } & \multirow{2}{*}{ 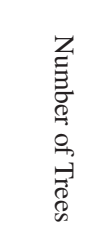 } & \multirow[b]{2}{*}{ 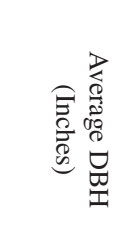 } & \multirow{2}{*}{ 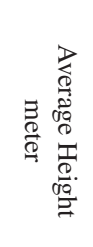 } & \multicolumn{5}{|c|}{ Weight from the tree $(\mathrm{kg})$} \\
\hline & & & & & & 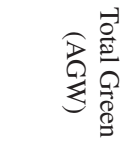 & 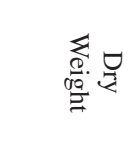 & 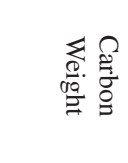 & 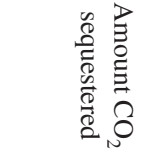 & 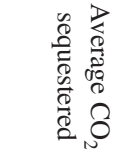 \\
\hline 1 & $\begin{array}{l}\text { Bodda Chet- } \\
\text { tu }\end{array}$ & Ficus hispida L.f & 38 & 26.77 & 7.5 & 967.45 & 701.40 & 350.70 & 1285.77 & 33.83 \\
\hline 2 & Garugu & $\begin{array}{l}\text { Trichilia connaroides } \\
\text { (Wight \& Arn.) Bentv. }\end{array}$ & 60 & 19.68 & 6 & 418.28 & 303.25 & 151.62 & 555.91 & 9.26 \\
\hline 3 & Burugu & Bombax ceiba L. & 45 & 84.64 & 14 & 18053.10 & 13088.49 & 6544.24 & 23993.18 & 533.18 \\
\hline 4 & Panasa & $\begin{array}{l}\text { Artocarpus heterophyllus } \\
\text { Lam. }\end{array}$ & 158 & 127.95 & 16 & 47149.06 & 34183.07 & 17091.53 & 62662.69 & 396.59 \\
\hline 5 & Chinta & Tamarindus indica $\mathrm{L}$. & 125 & 94.48 & 15.5 & 24904.85 & 18056.01 & 9028.0 & 33099.38 & 264.79 \\
\hline 6 & Mamidi & Mangifera indica $\mathrm{L}$. & 180 & 124.06 & 20 & 55407.18 & 40170.20 & 20085.10 & 73638.01 & 409.10 \\
\hline 7 & Neelagiri & Eucalyptus globulus & 55 & 70.87 & 32 & 28929.92 & 20974.19 & 10.487 .09 & 38448.85 & 699.07 \\
\hline 8 & Silver Oak & Grevillea robusta & 150 & 53.14 & 26.5 & 13469.81 & 9765.61 & 4882.80 & 17901.83 & 119.34 \\
\hline 9 & Ravi & Ficus religosa & 6 & 98.42 & 18 & 31384.24 & 22753.58 & 11376.79 & 41710.72 & 6951.78 \\
\hline 10 & Nallajeedi & $\begin{array}{l}\text { Semecarpus anacardi- } \\
\text { um L.f. }\end{array}$ & 12 & 17.71 & 7.50 & 423.41 & 306.97 & 153.48 & 562.73 & 46.89 \\
\hline 11 & Veduru & Bambusa vulgaris & 95 & 7.87 & 10.5 & 195.10 & 141.44 & 70.72 & 259.29 & 2.272 \\
\hline 12 & Jeelugu & Caryota urens $\mathrm{L}$. & 24 & 53.14 & 17 & 8641.01 & 6264.73 & 3132.36 & 11484.19 & 478.50 \\
\hline 13 & Kanugu & $\begin{array}{l}\text { Pongamia pinnata } \\
\text { (L.) Pierre }\end{array}$ & 15 & 66.92 & 13 & 10479.19 & 75974.12 & 37987.06 & 139271.95 & 9284.79 \\
\hline 14 & Sampangi & $\begin{array}{l}\text { Micheliachampaca } \\
\text { (L.) Baill.ex Pierre }\end{array}$ & 8 & 45.27 & 18 & 6639.96 & 4813.97 & 2406.98 & 8824.74 & 1103.09 \\
\hline 15 & Teku & Tectona grandis L.f & 250 & 70.86 & 17.5 & 15816.58 & 11467.02 & 5733.51 & 21020.78 & 84.083 \\
\hline 16 & Peddaturayi & Delonix regia & 10 & 90.55 & 12.5 & 18448.43 & 13375.11 & 6687.55 & 24518.58 & 2451.85 \\
\hline 17 & Marri Chettu & Ficus benghalensis L. & 5 & 177.16 & 17 & 96040.13 & 69629.09 & 34814.54 & 127640.58 & 25528.11 \\
\hline 18 & Neredu & $\begin{array}{l}\text { Syzygium cumini } \\
\text { (L.) Skeels }\end{array}$ & 16 & 92.51 & 16 & 24647.32 & 17869.31 & 8934.65 & 32757.13 & 2047.32 \\
\hline 19 & Nalla Maddi & Terminalia alata Roth. & 27 & 88.58 & 18 & 25422.38 & 18431.23 & 9215.61 & 33787.21 & 1251.37 \\
\hline 20 & Tella Maddi & $\begin{array}{l}\text { Terminalia arjuna (Roxb. } \\
\text { ex DC.) }\end{array}$ & 32 & 93.30 & 17.5 & 27420.40 & 19879.79 & 9939.89 & 36442.64 & 2024.59 \\
\hline 21 & Rela & Cassia fistula $\mathrm{L}$. & 18 & 26.77 & 8 & 1031.95 & 748.16 & 374.08 & 1371.49 & 76.194 \\
\hline 22 & Pampini & $\begin{array}{l}\text { Oroxylum indicum (L.) } \\
\text { Kurz. }\end{array}$ & 21 & 22.04 & 7.5 & 655.77 & 475.43 & 237.71 & 871.55 & 41.50 \\
\hline \multicolumn{2}{|c|}{ TOTAL } & & 1350 & 1552.69 & 335.5 & 456545.5 & 399372.2 & 189198.9 & 732109.2 & 53837.5 \\
\hline
\end{tabular}

is no direct relationship between the height of the tree and the $\mathrm{CO}_{2}$ sequestration in the sampling locations. Rowntree (1984) revealed that the height of the tree contributes to the volume of the tree which can be related to the mass and consequently the relative $\mathrm{CO}_{2}$ sequestration potential of the tree. The linear regression equation of $y=2713.285803 x-$ 209800.8762 with $\mathrm{R}^{2}=0.553$ demonstrates the height of tree species with carbon dioxide sequestered, indicating the insignificant variations between the tree species height with the rate of $\mathrm{CO}_{2}$ sequestered at $\mathrm{P}>0.05$. The number of trees is also the major contributor to the rate of sequestration of carbon, followed by the size of the tree, which increases quickly as the number of individuals in a species increases, and then stabilizes. According to Vishnu and Patil (2016), the tree with the highest DBH has higher carbon stock. Baishya et al. (2009) found that biomass and carbon sequestration 
vary with $\mathrm{DBH}$, with maximum trees during the regeneration stage and high biomass of larger trees. Fast-growing trees capture more carbon than slow-growing trees (Montagnini \& Porras 1998, Redondo- Brenes 2007).

\section{Soil Organic Carbon}

Carbon sequestered in the soil is called hummus, giving maximum storage of carbon than the biomass. The SOC of Chinthuru Lothugedda Junction, block-1 is (0.93\%), Chinnagedda village, block-2 is $(0.22 \%)$, Near St.Ann's School, block-3 is $(0.88 \%)$ and Thajangi village, block-4 is (1.24). The observations show only little amount of SOC was noted in the sampling blocks, except for Thajangi village (block-4), which had (1.24\%) maximum SOC compared to all the other locations.

Depending on land use management, the soil could be a source of $\left(\mathrm{CO}_{2}, \mathrm{CH}_{4}\right.$, and $\left.\mathrm{N}_{2} \mathrm{O}\right)$ or a sink $\left(\mathrm{CO}_{2}\right.$ and $\left.\mathrm{CH}_{4}\right)$ of global greenhouse gases (Lal \& Bruce 1999, Lal \& Kimble 1998). SOC in this study sites would not be a major contributor to carbon dioxide sequestration due to the negligible levels of SOC. Bouwman (1990) showed the size has been estimated between 700 to 3,000 Gt carbon as organic carbon and 780 to $930 \mathrm{Gt} \mathrm{C}$ as Calcium carbonate $\left(\mathrm{CaCO}_{3}\right)$. Other carbon pools are the oceans $(38,000 \mathrm{Gt} \mathrm{C})$, fossils carbon reserves $(6,000 \mathrm{Gt} \mathrm{c})$, and $\mathrm{CO}_{2}$ in the atmosphere $(720 \mathrm{Gt} \mathrm{c})$.

The linear regression presented in Fig. 4 and Table 6 reveals that SOC has an insignificant impact on $\mathrm{CO}_{2}$ sequestered. The Dependent Variable $\mathrm{CO}_{2}$ sequestered was regressed on Predicting variable SOC to the test the relationship, SOC insignificantly, predicted $\mathrm{CO}_{2}$ sequestrated $\mathrm{F}(5.83,2.62)=0.2236 ; \mathrm{P} \geq 0.25$, which indicates that the SOC play an insignificant role in $\mathrm{CO}_{2}$ sequestration $(\beta=$ $102780.3 \mathrm{P} \geq 0.05)$. It was discovered that there was no direct relationship between the SOC and R2 $=0.100$, indicating that the regression model explains $100 \%$ of the variance. Table 6 below shows the summary of the findings and the results of linear regression. Table 6 reveals that both SOC and the rate of $\mathrm{CO}_{2}$ sequestration in trees have a regression equation of $y=10278 x+50863$ with $\mathrm{R} 2=0.100$, indicating that there are no significant differences between tree height and $\mathrm{CO}_{2}$ sequestration at $\mathrm{P}>0.05$ of the tree species' $\mathrm{CO}_{2}$ sequestration rate.

\section{CONCLUSION}

The total average potential of carbon sequestration of various tree species was calculated in four different sites (Block1 to 4) and was $12852.34 \mathrm{~kg}, 28769.48 \mathrm{~kg}, 64003.93 \mathrm{~kg}$, and $53837.5 \mathrm{~kg}$ respectively.

Therefore, it is concluded that the local trees of the forest have a large carbon concentration and stocks of carbon. In this study, the native tree species $T$. grandis L.f, $M$. indica, and T. indica L., P. pinnata (L.), A. heterophyllus Lam, L. $M$. indica L., F. religiosa L., and F. benghalensis L. Pierre, recorded the maximum amount of carbon dioxide sequestration and carbon storage, which facilitate to build up the ecological services, thereby reducing global warming.

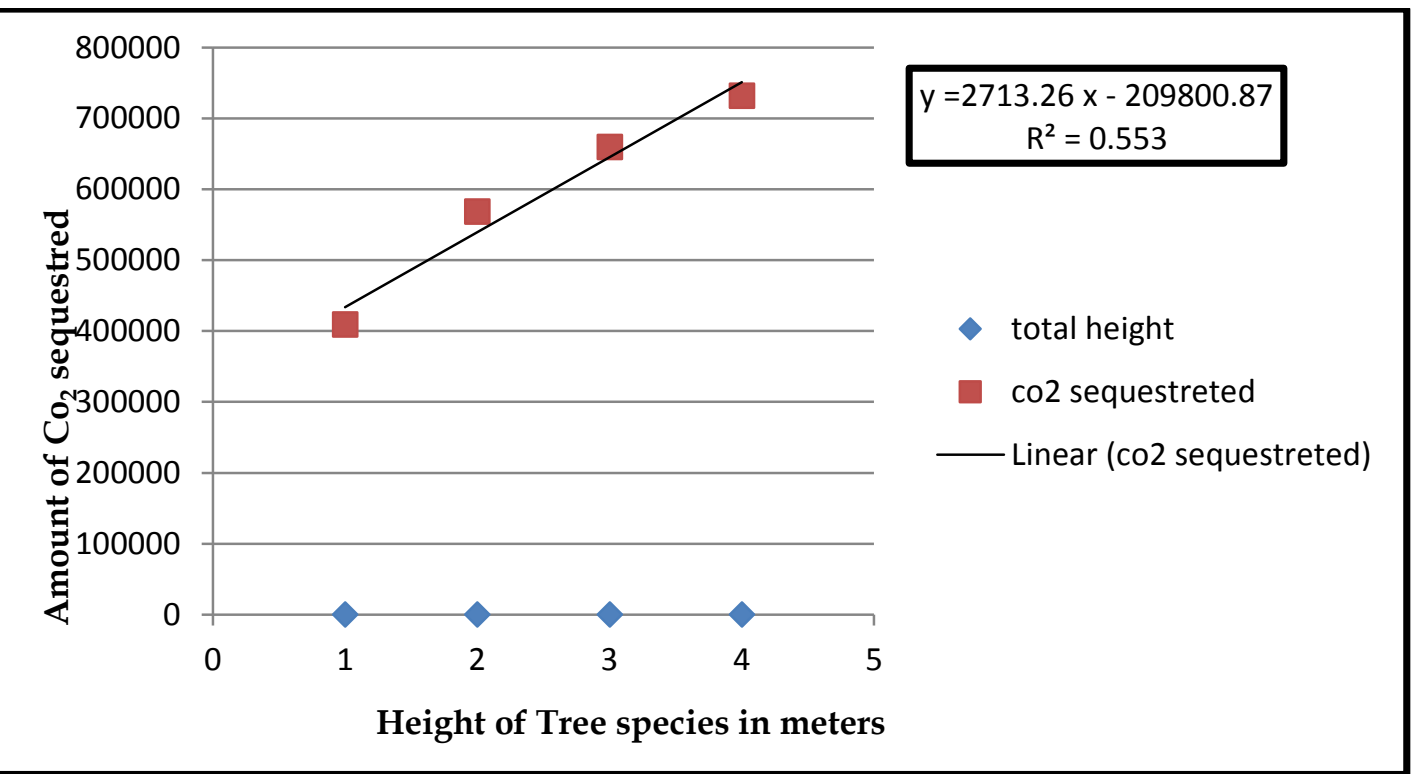

Fig. 3: Relationship between heights of the tree to the total amount of $\mathrm{CO}_{2}$ sequestered 
Table 5: The physico-chemical parameters, $\mathrm{pH}$, Soil texture, and SOC.

\begin{tabular}{|c|c|c|c|c|c|c|}
\hline \multirow{2}{*}{ S.No. } & \multirow[t]{2}{*}{ Sampling Station } & \multirow[t]{2}{*}{$\mathrm{pH}$} & \multicolumn{3}{|c|}{ Soil Texture } & \multirow[t]{2}{*}{ Organic Carbon\% } \\
\hline & & & Sand $\%$ & Silt\% & Clay\% & \\
\hline 1. & Chinthuru Lothugedda Junction- (block-1) & 6.28 & 71 & 12 & 17 & 0.93 \\
\hline 2. & Chinnagedda village-(block-2) & 6.22 & 61 & 15 & 25 & 0.22 \\
\hline 3. & Near St.Anns School, (block-3) & 7.81 & 45 & 26 & 29 & 0.88 \\
\hline 4. & Thajangi village (block-4) & 6.78 & 66 & 16 & 16 & 1.24 \\
\hline
\end{tabular}

Note: All the above parameters are analyzed as per IS2720 \& ASTM methods.

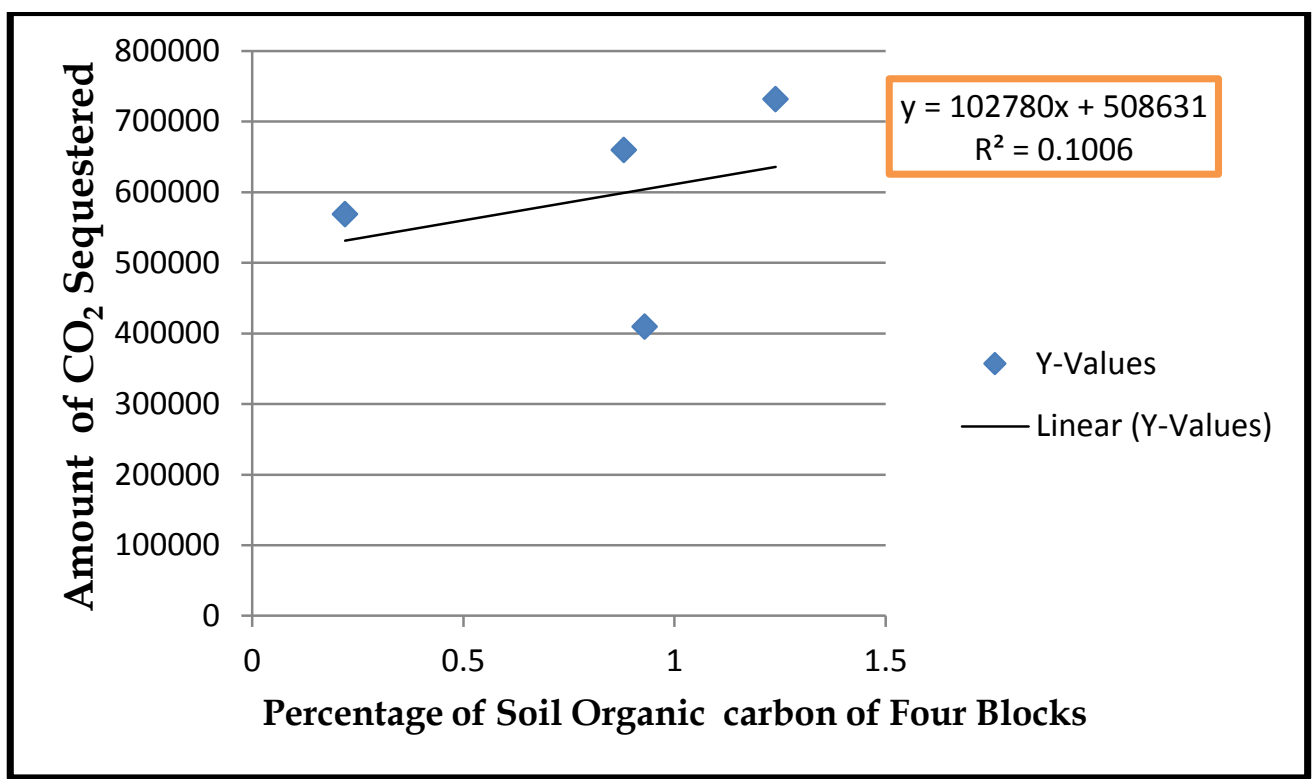

Fig. 4: Relationship soil organic carbon against the total amount of $\mathrm{CO}_{2}$ sequestered.

Furthermore, because these trees protect the Earth from the greenhouse effect and climatic change, they must be protected against deforestation, and sustainable forest management with the goal of carbon sequestration should be mandated. Plantation initiatives can be used to generate carbon credits, which can help developing countries generate income (Niles et al. 2002).

Because there is a need for proper organization and protection of biodiversity in the hilly forest areas which are the major source of carbon sinks, the findings of this study may assist future planning and decision-making by the forest department regarding native species selection and plantation, which would be the major contributors of high $\mathrm{CO}_{2}$ sequestration for the ecological balance of the Eastern Ghats reserve forest. Due to its high elevation from sea level, thick green forest, and low rural anthropogenic emissions of carbon components, the temperature of this area may drop to $0^{\circ} \mathrm{C}$, especially in the winter season, and hence it is the coolest hill station of Andhra Pradesh.

\section{REFERENCES}

Annissa Muhammed, A., Surendra, B., Keredin, T.S. and Solomon Raju,

Table 6: The Regression Analysis of the height of tree and $\mathrm{SOC}$ to $\mathrm{CO}_{2}$ sequestrated.

\begin{tabular}{|lllllll|}
\hline S.No. & Regression weights & $\beta$ - coefficient & $\mathrm{R}^{2}$ Value & F Value & P-Value & Hypothesis supported \\
\hline 1. & $\begin{array}{l}\text { Height of tree }-\mathrm{CO}_{2} \mathrm{Se}- \\
\text { questered }\end{array}$ & 2713.286 & 0.553 & 2.478262 & 0.256093 & No \\
2. & $\begin{array}{l}\text { Soil Organic Carbon }- \\
\mathrm{CO}_{2} \text { Sequestered }\end{array}$ & 102780.3 & 0.1005 & 0.2236 & 0.682343 & No \\
\hline
\end{tabular}


A.J. (2013), Assessment of biomass and carbon sequestration potentials of standing Pongamia pinnata in Andhra University, Visakhapatnam, India. Biosci. Discov., 4(2): 143-148

Baishya, R.S., Barik, K. and Upadhya, K.2009. Distribution pattern of above-ground biomass in natural and plantation forests of humid tropics in northeast India. Trop. Ecol., 50(2): 295-304.

Bouwman, A.F. 1990. Soils and greenhouse effect. John Willey and Sons, New York, USA.

Brown S. and Lugo, A.E. 1982. The storage and production of organic matter in tropical forests and their role in the global carbon cycle. J. Biotropica., 14: 161-187.

Brown, S. 1997. Estimating Biomass Change of Tropical Forests: A Primer. Forestry, Paper, FAO, Rome, Italy, p. 134.

Brown, S., Gillespie, A.J.R. and Lugo, A.E. 1989. Biomass estimation methods for tropical forests with applications to forest inventory data. For. Sci., 35: 881-902.

Brown, S., Gillespie, A.J.R. and Lugo, A.E. 1991. Biomass of tropical forests of South and Southeast Asia. Can. J. For. Res., 21: 11-117.

Chavan, B.L. and Rasal, G.B. 2010. Sequestered standing carbon stock in selective tree species grown in University campus at, Aurangabad, Maharashtra, India. Int. J. Eng. Sci. Technol., 2 (7): 3003- 3007.

Chhabra A and Dadhwal, V.K. 2004. Assessment of major pools and fluxes of carbon in Indian forests. Climate Change, 64: 341-360.

Clark, D.A., Brown, S., Kicklighter, D.W., Chambers, J.Q., Thomlinson, J.R., Ni, J. and Holland, E.A. 2001. Net primary production in tropical forests: An evaluation and synthesis of existing field data. Ecol. Appl., 11: 371-384.

Cox, H.M. 2012. A sustainability initiative to quantify carbon sequestration by campus trees. J.Geogr., 20: 111-138.

Crookshank, S.L. 1999. Carbon Sinks and the Kyoto Protocol. Discussion Paper No. 091, American Petroleum Institute, Washinton DC, USA.

De Villiers, C., Chen, S. and Zhu, Y. 2014. Carbon sequestered in trees on a University campus: A case study. Sustain. Account. Manag. Policy J., 5: 149-171.

Djomoa, A.N., Ibrahima, A., Saborewskic, J. and Gravenhorsta, J. 2010. Allometric equations for biomass estimations in Cameroon and pan moist tropical equations including biomass data from Africa. 260(10): 1873-1885

Fang, J., Chen, A., Peng, C., Zhao, S., and Ci, L. 2001. Changes in forest biomass carbon storage in China between 1949 and 1998. Science, 292: $2320-2322$.

Food and Agricultural Organization (FAO). 2005. State of the World's Forests. FAO, Rome.

Gibbs, H.K., Brown, S., Niles, J.O. and Foley, J.A. 2007. Monitoring and estimating tropical forest carbon stocks: Making REDD a reality. Environ. Res. Lett., 2: 045023

Gorte, R. 2009. Carbon sequestration in forests, Congressional Research Service Report for Congress. 1-5

Gupta, H.S. 2009. Forest as a carbon sink: Temporal analysis for Ranchi district. Indian J. For., est 32(1): 7-11

Haghparast, H., Delbari, A. and Kulkarni, D.K. 2013. Carbon sequestration in Pune university campus with special reference to Geographical Information System (GIS). Ann. Biol. Res., 4: 169-175.

Haripriya, G.S. 2000. Estimate of biomass in Indian forests. Biomass Bioenerg., 19: 245-258

Haripriya, G.S. 2001. A framework for the carbon stored in Indian wood products. Environ. Dev. Sustain., 3: 229-251

Haripriya, G.S. 2003.Carbon Budget of the Indian Forest Ecosystem. Climate Change, 56: 291-391.

Houghton, R.A. 1985. Net flux of carbon dioxide from tropical forest in
1980. Nature, 316

Houghton, R.A., Skole, D.L., Nobre, C.A., Hackler, J.L., Lawrence, K.T. and Chomentowski, W.H. 2000. Annual fluxes of carbon from deforestation and regrowth in the Brazilian Amazon. Nature, 403: 301-304.

Houghton, R.A. 1990. The future role of tropical forest in affecting the carbon dioxide concentration of the atmosphere. Ambio, 19: 204-209.

IPCC. 2003. Good Practice Guidance for Land Use, Land-Use Change, and Forestry. IPCC National Greenhouse Gas Inventories Programme, Kanagawa, Japan.

Kaul, M., Dadhwal, V.K. and Mohren, G.M.J. 2009. Land use change and net C flux in Indian forests. For. Ecol. Manage., 258: 100-108

Kaur, K. and Sharma, S. 2014. Potential of agroforestry, inventorization, distribution pattern, and phytosociological analysis of tree species in block Ramgarh, Samba (J\&K), India. Int. J. Adv. Agric. Sci. Technol., 2(6): 19-25

Lal, R. and Bruce, J.P. 1999. The potential of world cropland soils to sequester $\mathrm{C}$ and mitigate the greenhouse effect. Environ. Sci. Policy, 2: 177-185.

Lal, R., Kimble, J.M. and Follett, R.F. 1998. Land use and soil C pools in the terrestrial ecosystem, Environ. Sci. Policy, 7: 1-10.

Lodhiyal, N. and Lodhiyal, L.S. 2003. Biomass and net primary productivity of Bhabar Shisham forests in central Himalaya, India. For. Ecol. Manage., 176(1-3): 217-235.

Lodhiyal, N., Lodhiyal, L.S. and Pangtey, Y.P.S. 2002. Structure and function of Shisham forests in Central Himalaya, India: Dry matter dynamics. Ann. Bot., 89(1): 41-54.

Manhas, R.K., Negi, J.D.S., Kumar, R., Chauhan P.S. 2006. temporal assessment of growing stock, biomass and carbon stock of Indian forests. Climatic Change, 74: 191-221

Montagnini, F. and Porras, C. 1998. Evaluating the role of the plantation as carbon sinks: An example of an integrative approach from the humid tropic. Environ. Manage., 22: 459-470.

Niles, J.O., Brown, S., Pretty, J., Ball, A.S. and Fay, J. 2002. Potential carbon mitigation and income in developing countries from changes in use and management of agricultural and forest lands. Philos. Trans. A Math. Phys. Eng. Sci., 360(1797):1621-1639.

Pussinen, A., Karjalainen, T., Makip, R., Valsta, L. and Kellom, A. 2002. Forest carbon sequestration and harvests in a Scots pine stand under different climate and nitrogen deposition scenarios. For. Ecol. Manage., 158(1-3): 103-115

Ravindranath, N.H. Somashekhar, B.S. and Gadgil, M. 1997. Carbon flow in Indian forests, submitted to the Ministry of Environment and Forest. Climate Change, 35(3): 297-320.

Redondo-Brenes, A. 2007. Growth, carbon sequestration, and management of negative tree plantation in the humid region of Costa Rica. New Forest, 34: 253-268.

Rowntree, R.A. 1984. Forest, canopy cover and land use in four eastern United States Cities. Urban Ecol., 8: 55-67.

Rowntree, R.A. and Nowak, D.J. 1991. Quantifying there of urban forest N removing atmospheric carbon dioxide. J. Arbori., 17: 269-275.

Singh, R. and Lal, M. 2000. Sustainable forestry in India for carbon mitigation. Curr.Sci., 78: 563-567.

Stephens, B.S. 2007. Weak northern and strong tropical land carbon uptake from vertical profiles of atmospheric $\mathrm{CO}^{2}$. Science, 316: 1732-1735.

Vishnu, P.R. and Patil, S.S. 2016. Carbon storage and sequestration by trees in and around the university campus of Aurangabad city, Maharashtra. Int. J. Innov. Res. Sci. Eng. Technol., 5(4): 5459-5468

Vucetich, J.A. Reed, D.D., Breymeyer, A., Deg'orski, M., Mroz, G.D., Solon, J., Roo-Zielinska, E. and Noble, R. 2000. Carbon pools and ecosystem properties along a latitudinal gradient in northern Scots pine (Pinus sylvestris) forests. For. Ecol. Manage., 136: 135-145 